\title{
BELOW THE MURCHISON FALLS
}

\section{By Robin Tomkinson}

For any one interested in birds and beasts, an expedition to the Murchison Falls in Uganda is a truly thrilling experience. On either side of the Victoria Nile, from Lake Albert to the Falls, is the Bunyoro and Gulu game reserve where, from a boat going up and down the river, one can see an amazing number and variety of African fauna. It is a perfect example of the intense pleasure to be had from watching wild animals in a place where they can live undisturbed by man.

We started about 7 p.m. on a very hot evening, from the little port of Butiaba, on Lake Albert. Just after boarding the Murchison we were beset by thousands upon thousands of small lake flies, which luckily did not sting, but got into absolutely everything, until we thought we should never be able to eat or drink without swallowing them in hundreds. But when we got out into the open water they disappeared and we were able to enjoy in peace the wonderful starry sky and the moon over the lake.

We anchored about 11 p.m. near the mouth of the Victoria Nile, and then retired to our bunks, but excitement combined with great heat made it hard to sleep. About 4.30 a.m. we heard the engine starting up, and by 5.30 were on deck to watch the sunrise-one of the most thrilling we had ever seen. It was still fairly dark and large shadowy bats were hawking about round the boat. Very quickly a pink glow appeared and soon the whole of the eastern sky was mother-of-pearl coloured, and this wonderful pink and bluish-green and gold was reflected in the oily-smooth waters of the Nile, while on either side of the river and apparently stretching for miles, were high walls of dark green papyrus with feathery heads. Then about twenty white cattle egrets crossed in front of us, flying low over the water, their white feathers turning pink in the sunrise, just as snow mountains do.

After that every moment brought "something rich and strange". There were parties of hippo everywhere, lying with their backs awash, but when they saw the boat they sank right down in the water, so that you could only see a dozen suspicious pairs of pink eyes and ears, sometimes very small eyes and ears alongside the big ones. The parts of a hippo which usually show above water are brownish pink, not greyish as we had supposed. Several times we surprised an old hippo having his breakfast on the bank, and he flopped into the water with outraged grunts, 


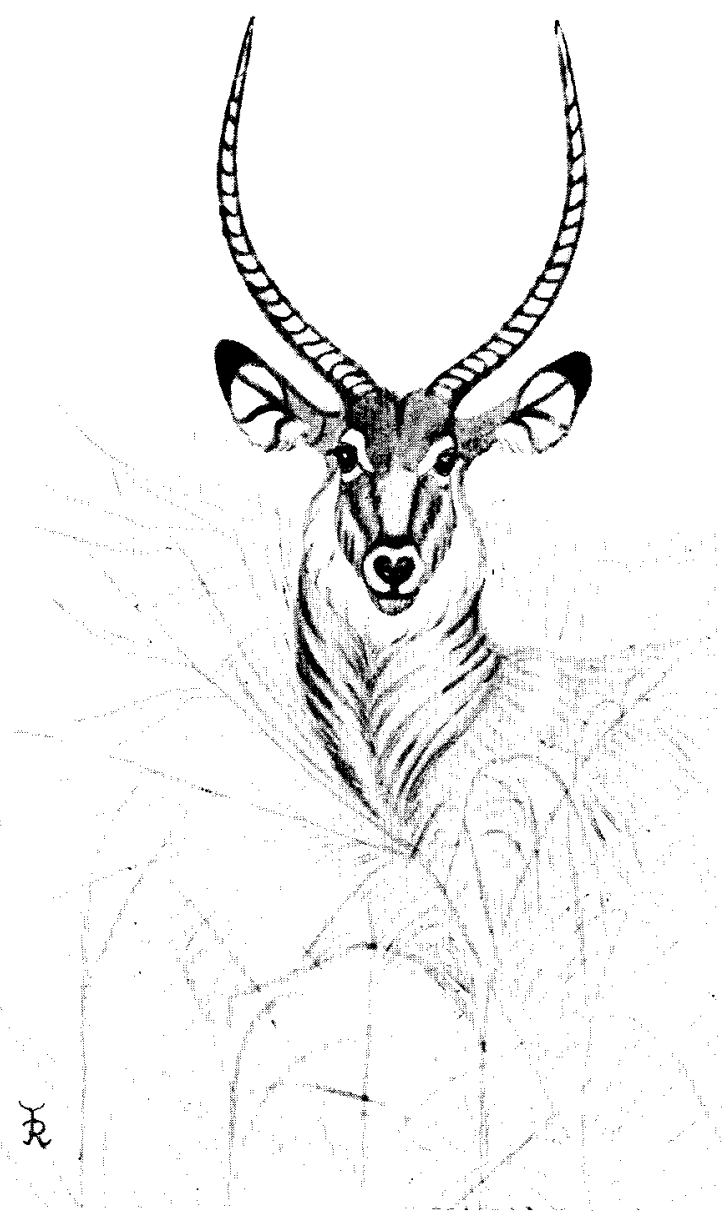

WATERBUCK. 

looking very stuffy at being interrupted. But generally, if undisturbed, hippos seem to exude contentment like ducks and pigs, and, like them, look rather as though they were made for a joke. On the sandbanks were innumerable crocodiles, basking in the sun, huge and repulsive looking brutes, especially when they lay with their mouths open; some were monsters which appeared to be at least 15 feet long. Now and then one slid into the water in a sluggish though purposeful way, but others were walking about on the shore quite fast, with legs upright and bodies clear of the ground.

In contrast to the crocodiles were many very beautiful and interesting birds. Little pied kingfishers hovered over the water " dive-bombing" the fish at intervals ; darters swam round us with nothing showing but a dark brown snake-like head and neck. Lily-trotters, brown and white and chestnut, with fantastically long toes, ran about on the edgc of the papyrus, and with them were great and lesser white egrets, various plovers, "Hadeda" ibis, and Egyptian and spur-winged geese. A flock of sacred ibis passed us in V-formation; they were very beautiful with their gracefully curved black beaks, black heads and necks, and pure white wings edged with black. But the two most notable birds were the goliath heron and the fish eagle. The goliath is really awe-inspiring, as he stands well over 5 feet high-a fact which I appreciated when I saw him through fieldglasses at the same time as an elephant. He has a reddish-brown neck, blue-grey back and wings, with white plumes, and a very lordly air. The fish eagle is just as much a king in his way, and is a surprising colour for an eagle, with his black and chestnut wings and pure white head and breast. There seemed to be one, or sometimes a pair, about every 200 yards down the river, and it was grand to watch them flying and soaring, and to hear their odd laughing call.

In the midst of all this we had breakfast on the upper deck, which meant that between most mouthfuls we had to seize our field-glasses to look at something new. As one watched a herd of waterbuck, about twenty hippos, some crocodiles and a goliath heron, someone on the opposite side would say in a tense whisper: "You must look at the rhino and the fish eagle behind you !" We had a grand view of a black rhino standing on some grassy flats by a stretch of the river where there was no papyrus. He had got wind of us, but could not see the boat with his short-sighted eyes, so he was ramping up and down in a fury with his nose in the air, looking for something to charge. Sitting unconcernedly on his back was a graceful white cattle egret, and 
a flock of ten or so were following him. Most of the hippos too and even the elephants, had their " entourage" of cattle egrets, a strange contrast to the enormous dark-coloured beasts.

Going upstream towards the Falls we saw only one elephant, but on the way back they appeared in numbers beyond our wildest dreams.

Just before 9 a.m. we anchored by the landing stage, about a mile and a half below the Falls. The view from there is wonderful ; forest on either side, and in the distance the white foaming water of the falls roaring down between the rocks, the rapids below them, and then the calmer water where the hippos can laze about in peace.

The path towards the Falls is steep and very hot, and on the way a game scout with a rifle leads, while another brings up the rear. We felt the wisdom of this when we found that for most of the way the path smelt strongly of elephants and there were signs of them everywhere. However, we saw nothing but birds and butterflies on the path, though in one place, where a dried-up sandy watercourse led down to the river, we saw the huge round marks made by the elephants' feet as they came down to drink. From the heights above the falls we looked down the Nile, thinking of all we had seen on the way up, and then a fish eagle sailed majestically across the gorge just below us.

About noon we started downstream in the Murchison, and by then it was so hot that all the elephants seemed to have decided to come down and bathe. The river banks were lined with themwe must have seen several hundred-and they were having a most blissful time in the water. Some were actually lying down in it, some were giving themselves shower-baths with their trunks, and the babies were splashing about on the edge, very like small children who can't quite make up their minds to go into the water. There was one very new "elephant's child", a most comic little person, certainly no more than $\mathbf{3}$ feet high. With him were two large elephants, one obviously mother, the other perhaps an "aunt". When they saw the boat the two big elephants closed in on the baby one on each side, and as one led the way back towards the forest the other kept the baby just between them by propelling him gently with her trunk.

As the river is pretty wide and shallow near the banks we were some way from the elephants and could only see details through field-glasses, but it was fascinating to watch them from such a good vantage point. Even so, as the boat was moving all the time one could never watch individual animals quite long enough, and it felt like watching a film which goes too 
fast. We saw a number of antelope, but generally for fleeting moments, as they move so quickly. Sometimes a waterbuck would show a suspicious head above the long grass or rushes, so we could see his beautiful horns and ears, and we saw one herd of them lying down peacefully like cows in a field. There were several parties of Uganda kob grazing by the river, looking in the distance rather like waterbuck, except for the completely different curve of their horns. Once an impala ram and a kongoni were surprised at the same instant by the Murchison. They took to their heels side by side, and the contrast was fantastic. The impala seemed the epitome of grace and the poetry of motion as he almost floated through the air, while the kongoni beside, or rather below, him, was all angles and very ungainly, looking like the caricature of an antelope, but none the less surprisingly fast.

One of the last things we saw before we came to Lake Albert was a magnificent bull elephant with very fine tusks, standing in a lordly way all by himself, with a white egret sitting on his back.

We said farewell to the last hippo just near the mouth of the river. This is fairly narrow, with $12-15 \mathrm{ft}$. "walls " of papyrus on either side, and owing to the strong current it needs skill to steer through it. We very nearly got caught in the papyrus but after a few anxious moments all was well and we were soon on the open lake, looking across at the hills of the Belgian Congo and almost unable to believe that we could have seen so many wonderful things in a single morning. We knew also that we must have passed by many things, especially birds, without being able to see or identify them, just because " the pace was too good to inquire". 